Contents list available at IJRED website

Int. Journal of Renewable Energy Development (IJRED)

Journal homepage: http://ejournal.undip.ac.id/index.php/ijred

\title{
Biogas Filter Based on Local Natural Zeolite Materials
}

\author{
Satriyo Krido Wahono* and Wahyu Anggo Rizal \\ Technical Implementation Unit for Development of Chemical Engineering Processes \\ Indonesian Institutes of Sciences, INDONESIA
}

\begin{abstract}
UPT BPPTK LIPI has created a biogas filter tool to improve the purity of methane in the biogas. The device shaped cylindrical tube containing absorbent materials which based on local natural zeolite of Indonesia. The absorbent has been activated and modified with other materials. This absorbtion material has multi-adsorption capacity for almost impurities gas of biogas. The biogas filter increase methane content of biogas for 5-20\%. The biogas filter improve the biogas's performance such as increasing methane contents, increasing heating value, reduction of odors, reduction of corrosion potential, increasing the efficiency and stability of the generator.
\end{abstract}

Keywords: biogas, biogas filter, electric conversion, local natural zeolite, methane concentration

Article History: Received Sept 24, 2013; Received in revised form Dec 13, 2013; Accepted January 16, 2014; Available online

How to Cite This Article: Wahono, S.K. \& Rizal, W.A. (2014) Biogas Filter Based on Local Natural Zeolite Materials. Int. Journal of Renewable Energy Development, 3(1), 1-5.

http://dx.doi.org/10.14710/ijred.3.1.1-5

\section{Introduction}

Indonesia is very rich with agricultural resources, where livestock is one of these resources. Beside as a food resource, the livestock also an energy source by converting livestock dung into biogas. Biogas is made by feeding cow dung into the digester tank through the input pipe. The fermentation process is influenced by several factors such as anaerobic conditions, substrate, $\mathrm{pH}$, temperature, agitation, moisture content, solids concentration, $\mathrm{C} / \mathrm{N}$ ratio, toxic materials, and length of fermentation substrate in the digester (Bughiarello et al. 1981; Tahir \& Mustafa 2007). The main composition of biogas is methane $\left(\mathrm{CH}_{4}\right)$ of $40-75 \%$. Whereas the most impurities gas is carbon dioxide $\left(\mathrm{CO}_{2}\right)$ and another impurities gas are hydrogen sulfide $\left(\mathrm{H}_{2} \mathrm{~S}\right)$, water vapor $\left(\mathrm{H}_{2} \mathrm{O}\right)$, nitrogen $\left(\mathrm{N}_{2}\right)$, hydrogen $\left(\mathrm{H}_{2}\right)$ and oxygen $\left(\mathrm{O}_{2}\right)$ (Monnet 2003; Muryanto 2006; Hambali 2007). If the methane content of biogas is under $60 \%$, biogas use as cooking fuel only and hardly convert into electricity (Febrisiantosa \& Julendra 2008). Therefore, tools or methods to increase methane content in biogas by reduce impurities gas was needed.

UPT BPPTK LIPI has improved a biogas filter tool or method to increase the purity of methane in the biogas based on local natural zeolite. Biogas purification is conducted by adsorption system using activated zeolite as an adsorbent. One of the natural zeolite deposits in Indonesia, which has a fairly large in amount $\left(55,000,000 \mathrm{~m}^{3}\right)$ with silica content approximately of $60 \%$, is the local natural zeolite of Gunungkidul Yogyakarta. These minerals often found in the hills area of Baturagung, Gedangsari District (Hargomulyo, Watugajah, Mertelu, and Tegalrejo Village) and Ngawen District (Tancep Village) (PEMKAB GUNUNG KIDUL 2013).

Zeolite structure performs adsorption and absorption of the compound $\mathrm{H}_{2} \mathrm{O}, \mathrm{CO}_{2}, \mathrm{SO}_{2}, \mathrm{H}_{2} \mathrm{~S}$ (Weitkamp \& Puppe 1999), with the gases absorption ability of zeolite is up to 25\% (Sutarti \& Rachmawati 1994). Zeolite control the main cause greenhouse effect gases of $\mathrm{CO}_{2}$ and $\mathrm{N}_{2} \mathrm{O}$, except $\mathrm{CH}_{4}$ (Delahay \& Coq 2002). Zeolite is able to absorb the main impurity gases of

\footnotetext{
* Corresponding author: Telp/Fax : (0274) 392570/391168

Email: dna_tqim@yahoo.com, satriyo.krido.wahono@gmail.com, satr002@lipi.go.id
} 
water vapor $\left(\mathrm{H}_{2} \mathrm{O}\right), \mathrm{CO}_{2}$ and $\mathrm{H}_{2} \mathrm{~S}$, not absorb the main gas of $\mathrm{CH}_{4}$ (Wahono et al. 2008).

Optimization of the natural zeolite performance is conducted through the activation stage. Natural zeolite is activated by heating (calcination) to evaporate the trapped water in the pores of zeolite crystals, so the surface area was increased (Sutarti \& Rachmawati 1994). In addition, zeolite is activated through dealumination process using acid solution. It was able to increase the surface area and pore volume, to reduce the mean pore spokes, to improve the ratio of $\mathrm{Si} / \mathrm{Al}$ and acidity of natural zeolite (Windarti 2002). After dealumination and calcination, natural zeolite Gunungkidul is better than the previous with higher $\mathrm{SiO}_{2} / \mathrm{Al}_{2} \mathrm{O}_{3}$ ratio (Widayat et al. 2008). This paper report the results of the biogas filter application based on local natural zeolite as an effort to improve the performance of biogas.

\section{Materials and Methods}

\subsection{Biogas Filter Preparation}

Cylindrical tube device contain absorbent which based on local natural zeolite of Indonesia. The device was connected to biogas digester as a biogas filter and shown in Figure 1. The absorption material was activated and modified with another local natural material. Gunungkidul natural zeolite were crushed to 100 mesh size, dealuminated with $\mathrm{HCl}$ for 24 hours, formed pellets with local kaolin Gunungkidul modification and calcined at $400{ }^{\circ} \mathrm{C}$ for 4 hours. Ratio of local kaolin : aquadest : local zeolite was $1: 3: 6$ in weight (Wahono et al. 2010).

\subsection{Biogas Filter Trial}

The biogas filter trials were conducted at some biogas installation locations and some types of generator capacity (1 HP, $3 \mathrm{HP}, 9 \mathrm{HP}$ ). In these trials were observed one or several parameters such as increasing methane content, cooking time, the colour of fire, electrical parameter, etc.

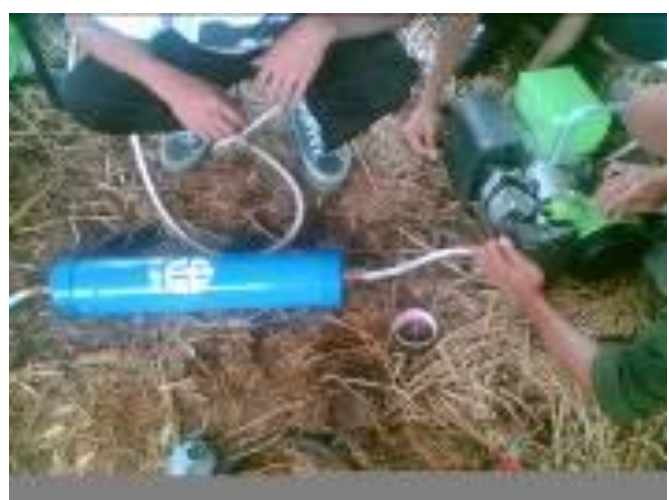

(a)

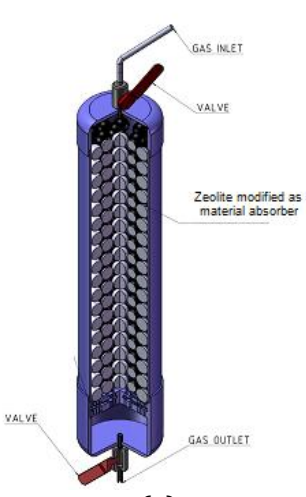

(a)

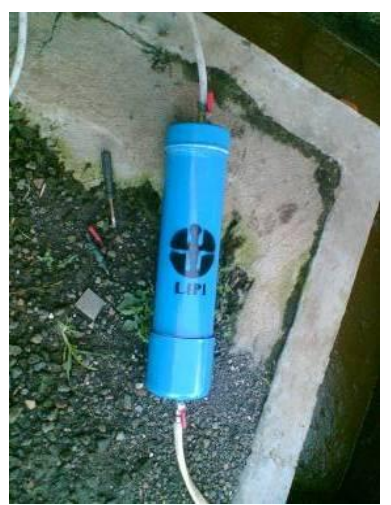

(b)

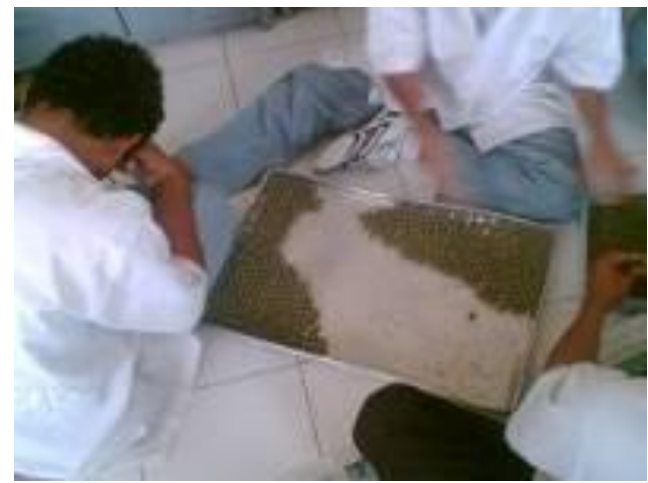

(c)

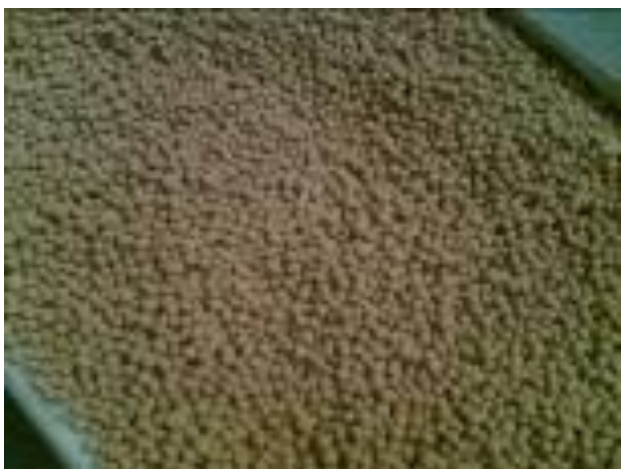

(d)

Fig. 1 The biogas filter : (a) Diagram; (b) Cylindrical tube; (c) Zeolite modification process; (d) Modified natural zeolite

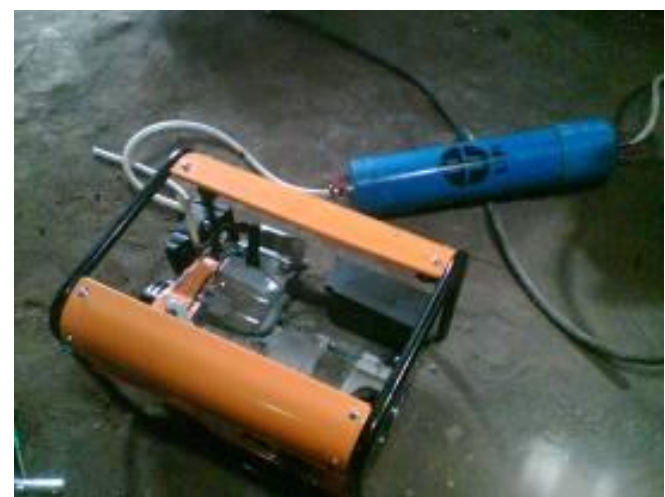

(b) 


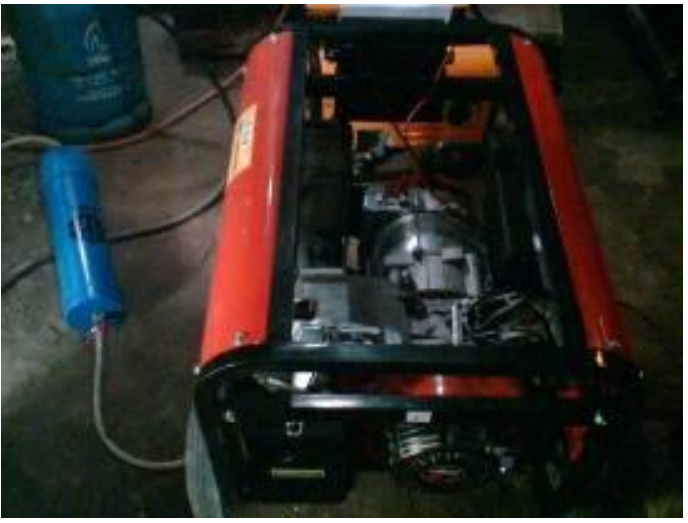

(c)

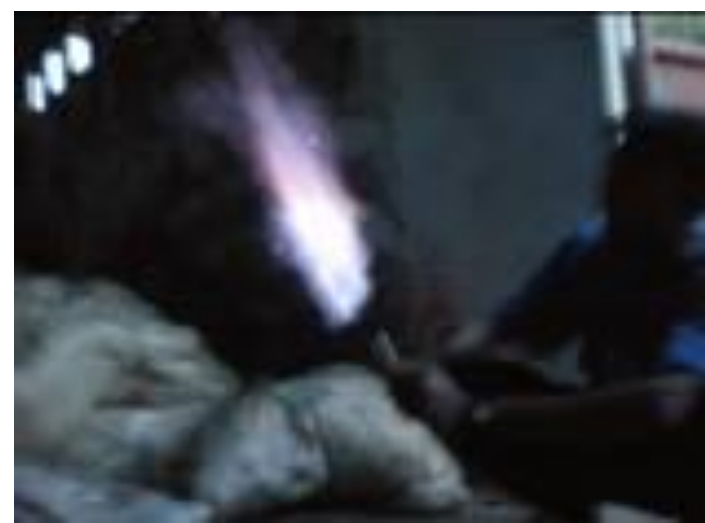

(e)

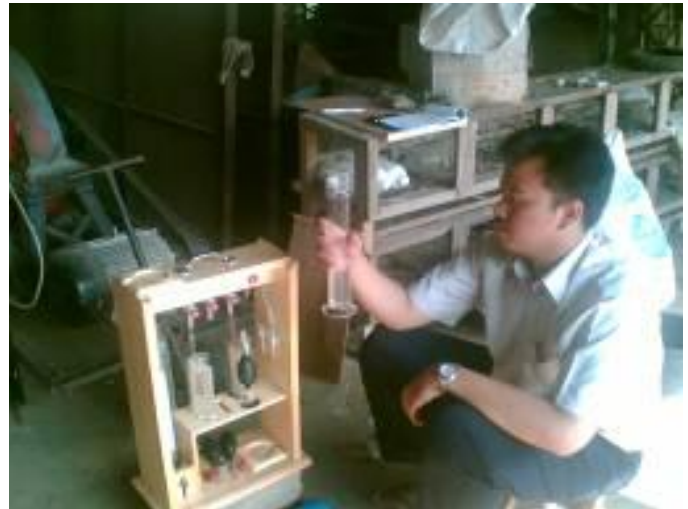

(d)

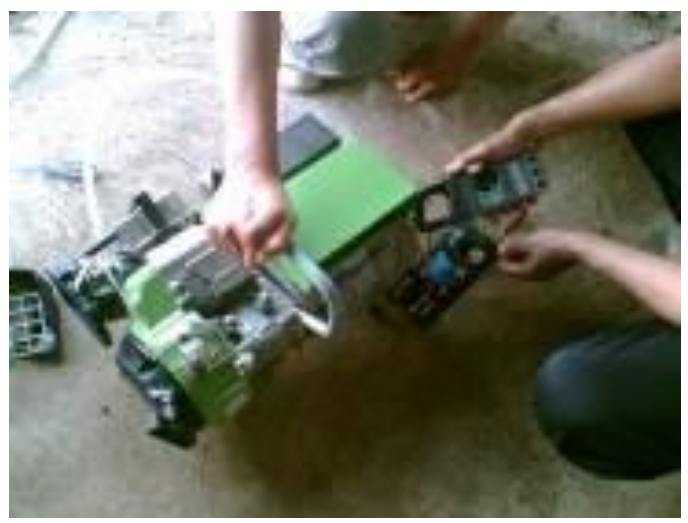

(f)

Fig. 2 The biogas filter trials, aplication and observation : (a) Application on 1 HP generator; (b) Application on 3 HP generator; (c) Application on 9 HP generator; (d) Gases Analysis (Orsat and GC); (d) Flame color observation; (e) Electrical observation

\section{Result and Discussion}

Trials and observations activities of biogas filter were shown at Fig. 2. The trials observe some parameters such as methane analysis using Gas Chromatography, gas analysis using Orsat method, flame color observations, cooking time and electrical parameters observations (electric current and voltage) on the generator applications.

Table 1

The results of biogas purification by alkaline solution and / or zeolite (Wahono et al. 2008)

\begin{tabular}{|c|c|c|c|c|}
\hline \multirow{2}{*}{$\begin{array}{l}\text { Absorber of } \\
\text { impurities } \\
\text { gas }\end{array}$} & \multirow{2}{*}{$\begin{array}{c}\text { Location } \\
\text { of biogas } \\
\text { installation }\end{array}$} & \multicolumn{3}{|c|}{$\begin{array}{l}\text { Methane content } \\
\text { of biogas (\%) }\end{array}$} \\
\hline & & Before & After & Increase \\
\hline \multirow{3}{*}{$\begin{array}{l}\mathrm{KOH} \\
\text { Solution }\end{array}$} & Gading-Playen & 62,5 & 77,4 & 14,9 \\
\hline & Bandung-Playen & 63,1 & 68,6 & 5,5 \\
\hline & Kepek-Wonosari & 64,1 & 72,3 & 8,2 \\
\hline $\mathrm{KOH}$ & & & & \\
\hline $\begin{array}{l}\text { Solution - } \\
\text { Nat. Zeolite } \\
\text { Hybrid }\end{array}$ & Gading-Playen & 73,3 & 97,3 & 24,0 \\
\hline $\begin{array}{l}\text { Synthetic } \\
\text { Zeolite }\end{array}$ & Gading-Playen & 75,2 & 93,2 & 15,0 \\
\hline $\begin{array}{l}\text { Nat. Zeolite } \\
\text { Modif. } 1\end{array}$ & Gading-Playen & 63,4 & 70,1 & 6,7 \\
\hline Nat. Zeolite & & & & \\
\hline $\begin{array}{l}\text { Modif. } 2 \text { /The } \\
\text { biogas filter }\end{array}$ & Gading-Playen & 61,2 & 81,7 & 20,5 \\
\hline
\end{tabular}

In the early of biogas filter development, the comparison with another biogas purification methods were conducted. It use absorbtion methods such as using alkaline solutions and synthetic zeolites. Methane content was determined by Gas Chromatography of PT Petrolab Service Jakarta which shown in Table 1.

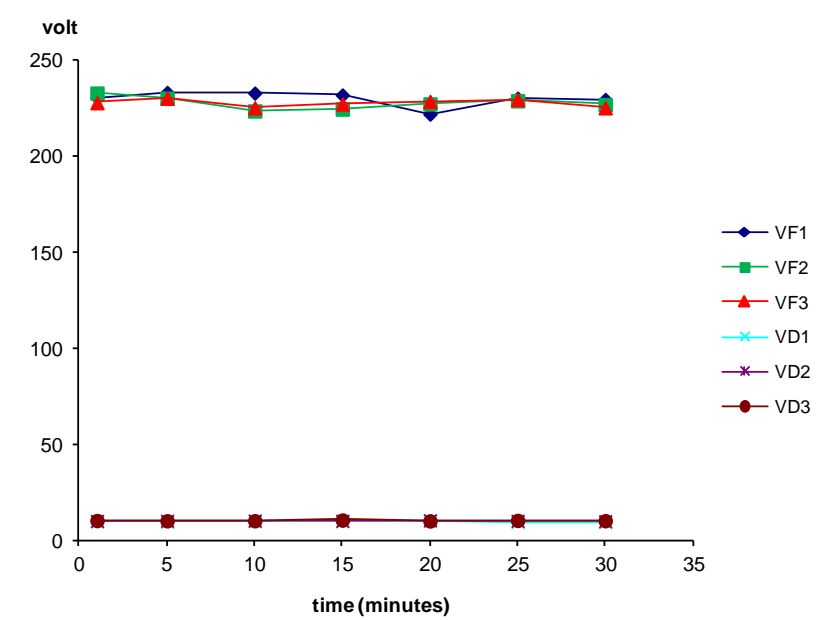

Fig. 3 Graphic of voltage vs time for using (VF) and without (VD) the biogas filter (Wahono et al. 2009) 
Citation: Wahono, S.K. \& Rizal, W.A. (2014) Biogas Filter Based on Local Natural Zeolite Materials. Int. Journal of Renewable Energy Development, 3(1), 1-5, doi: 10.14710/ijred.3.1.1-5

$\mathrm{P}$ a g e $\mid \mathbf{4}$

Table 2

The data of electric properties generator using the biogas filter (Wahono et al. 2009)

\begin{tabular}{|c|c|c|c|c|c|c|c|c|}
\hline \multirow{2}{*}{ Data } & \multicolumn{7}{|c|}{ Time (minute) } & \multirow{2}{*}{ Range } \\
\hline & 1 & 5 & 10 & 15 & 20 & 25 & 30 & \\
\hline \multirow{3}{*}{$\begin{array}{c}V_{\text {avg }} \\
\text { (Volt) }\end{array}$} & 231 & 234 & 233 & 232 & 222 & 231 & 230 & \multirow{3}{*}{$222-234$} \\
\hline & 233 & 231 & 224 & 225 & 228 & 229 & 227 & \\
\hline & 228 & 231 & 226 & 228 & 229 & 230 & 226 & \\
\hline \multirow{3}{*}{$\begin{array}{c}\mathrm{A}_{\mathrm{avg}} \\
\text { (Ampere) }\end{array}$} & 1,27 & 1,27 & 1,27 & 1,33 & 1,30 & 1,30 & 1,37 & \multirow{3}{*}{$1,07-1,37$} \\
\hline & 1,27 & 1,27 & 1,07 & 1,27 & 1,33 & 1,27 & 1,23 & \\
\hline & 1,27 & 1,27 & 1,27 & 1,20 & 1,27 & 1,27 & 1,27 & \\
\hline \multirow{3}{*}{$\begin{array}{c}\mathrm{P}_{\mathrm{avg}} \\
\text { (Watt) }\end{array}$} & 293 & 296 & 296 & 310 & 289 & 300 & 314 & \multirow{3}{*}{$239-310$} \\
\hline & 296 & 292 & 239 & 285 & 304 & 290 & 280 & \\
\hline & 289 & 292 & 286 & 273 & 290 & 291 & 286 & \\
\hline
\end{tabular}

Note $: \mathrm{V}=$ voltage; $\mathrm{A}=$ current; $\mathrm{P}=$ power; avg = average

Table 3

The biogas filter utilization at UPT Kapitan Meo, Belu-NTT (Wahono et al. 2009)

\begin{tabular}{|c|c|c|c|}
\hline Properties & Without the biogas filter & Using the biogas filter & $\begin{array}{c}\text { Increase } \\
\text { performance }\end{array}$ \\
\hline Cooking time of $200 \mathrm{cc}$ water & 312 seconds & 260 seconds & $\begin{array}{c}52 \text { seconds }(16,7 \%), \text { increase heating } \\
\text { value }\end{array}$ \\
\hline Flame color observation & $\begin{array}{l}\text { Blue with yellow-red } \\
\text { impurities }\end{array}$ & Clean blue & $\begin{array}{l}\text { More perfectly combustion, so reduce } \\
\text { soot }\end{array}$ \\
\hline Generator test & $\mathrm{OK}$ & $\mathrm{OK}$ & Corrosion potential reduction \\
\hline Methane content & $40,78 \%$ & $46,05 \%$ & $5,27 \%$ \\
\hline
\end{tabular}

Based on Table 1, the highest result was obtained by purifying of $\mathrm{KOH}$ solution - Natural Zeolite Hybrid. However, utilization of alkaline solution was less effective relatively due to quickly saturated. Therefore, zeolite material was used for the further development, especially for the natural zeolite modification 2 as the second highest methane content difference.

Electrical parameter data were taken from the biogas filter aplication using generator (1 HP). They are electric current and voltage value which determined by ampere - volt meter when connected to hand grinder machine $(670 \mathrm{~W})$. The data of electric voltage between using the biogas filter (VF1, VF2, VF3) and without the biogas filter (VD1, VD2, VD3) were shown at Figure 3. It show that there is significant different in voltage and significant effect for application in electric equipment. The machine unactivate $(9-11 \mathrm{~V})$ without the biogas filter, but the machine work correctly $(222-234 \mathrm{~V})$ when using the biogas filter. It was happened due to utilization of biogas filter resulting higher methane content on biogas. In addition, data of Table 2 show that generator electric parameter was in stable condition.

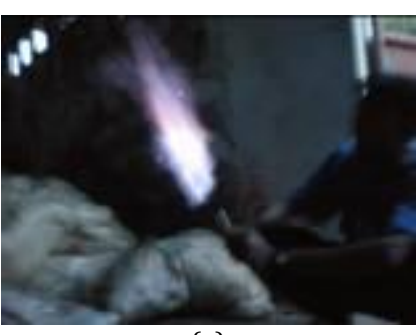

(a)

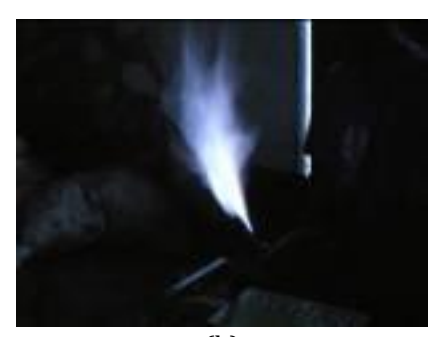

(b)
Fig. 4 Flame color observation : (a) Without the biogas filter; (b) Using the biogas filter
Some biogas filter observations were conducted at biogas plant in UPT Kapitan Meo, Belu - NTT. The observations were cooking time, flame color, generators test, and methane contents which shown in Table 3 and Figure 4 . The biogas filter improve the performance and quality of biogas. In addition, the presence of the biogas filter reduces corrosion potential on engine generator due to acid $\left(\mathrm{H}_{2} \mathrm{~S}\right)$ and water vapor was reduced.

Based on some trials, tests and observations, it was concluded that the biogas filters increase methane content of biogas about 5-20\%, increase heating value, reduce odors (reduce $\mathrm{H}_{2} \mathrm{~S}$ ), increase energy conversion efficiency and stability of generator (convertion energy into electricity), and reduce the corrosion potential for the engine.The biogas purification efforts were part of safely alternative energy storage solutions for biogas by converting into electricity which shown in the diagram of Fig. 5.

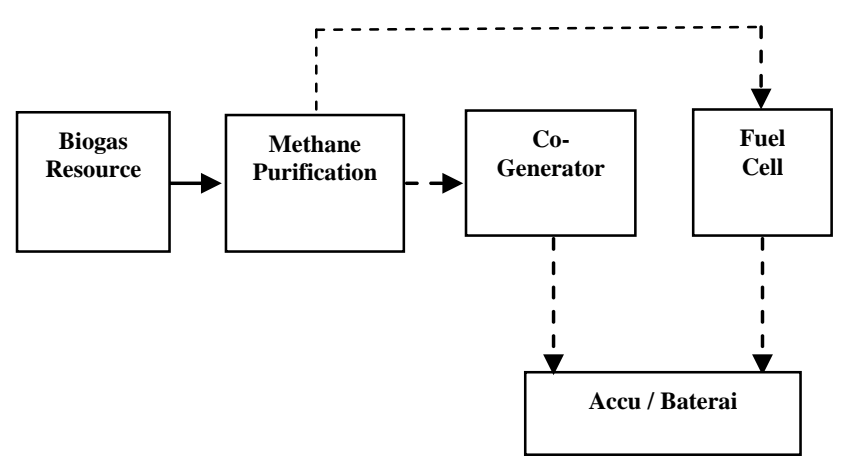

Fig. 5 The diagram of biogas energy storage as electricity using cogenerator and fuel cell (Wahono 2007) 


\section{Conclusion}

The biogas filter, based on modified local natural zeolite, improve the performance of biogas such as increasing methane contents, increasing heating value, reduction of odors, reduction of corrosion potential, increasing the efficiency and stability of the generator. On the other hand, this material is able to develope/ use for further purification of various pollutant gases such as in the chimney of factory, the motor vehicles and others.

\section{Acknowledgements}

The authors are thankful to UPT BPPTK LIPI Yogyakarta especially for Alternative Energy Team, Integrated Farming System Team, and Chemical and Environmental Technology Team for support of facilities in this research.

\section{References}

PEMKAB GUNUNG KIDUL (2013). Potency. http://www.gunungkidulkab.go.id/home.php?mode=content\&id $=307$. Accesed on Monday, July 1st, 2013.

Bughiarello, G., Brown, H., \& Byrom, F. L. (1981) Energy for Rural Development (Renewable Resource and Alternative Technologies for Developing Countries), National Academy Press, Washington

Delahay, G. \& Coq, B. (2002) Pollution Abatement Using Zeolite : State of The Art and Further Needs, Catalytic Science Series - Vol. 3, Zeolite for Cleaner Technologies, Chapter 16, Imperial College Press, London

Febrisiantosa, A. \& Julendra, H. (2008) Konversi Limbah Ternak Sapi Bali Bos Javanicus Menjadi Biogas di UPT Kapitan Meo Kab. Belu Nusa Tenggara Timur, Proceeding on Seminar Nasional Rekayasa Kimia dan Proses. ISSN : 1411 - 4216, Chemical Engineering Department, Diponegoro University, Semarang

Hambali, E., Mujdalipah, S., Tambunan, A. H., Pattiwiri, A. W., \& Hendroko, R. (2007) Bioenergy Technology, Agro Media Library. ISBN : 979-006-113-7

Monnet, F. (2003) An Introduction to Anaerobic Digestion of Organic Waste. Remade Scotland

Muryanto, J. P., Suprapto, Ekaningtyas, \& Sudadiyono (2006) Biogas, Green Alternative Energy, Matter 1, Institute for Agricultural Technology (BPTP), Central Java, Ungaran-Semarang.
Sutarti, M. \& Rachmawati, M. (1994) Zeolite Literature Review, Scientific Information and Documentation Centre, Indonesian Institute of Sciences, Jakarta.

Wahono, S. K. (2007) Review: Alternative Energy Storage Optimization and Safely on Biogas System, Proceeding Call For Paper - Young Engineer Contribution for Indonesia, ISBN : 979-258870-1, Jogja Engineer Meeting, Yogyakarta.

Wahono, S. K. (2008) Review: Use of Local Zeolite Gunungkidul Yogyakarta for Biogas Systems Optimization, Proceeding on Seminar Nasional Fundamental dan Aplikasi Teknik Kimia, ISSN : 1410-5667, Chemical Engineering Department, Institute Technology of Sepuluh November, Surabaya

Wahono, S. K., Maryana, R., Kismurtono, M., \& Sumarno (2008) Fuel Development of Fuel Cell from Biogas, Technical Research Report of DIPA UPT BPPTK LIPI, Yogyakarta

Wahono, S. K., Julendra, H., \& Febrisiantosa, A. (2009) Biogas Performance Improvement Through Methane Purification Technology at UPT Kapitan Meo, Belu - East Nusa Tenggara, Proceeding on Seminar LIPI - UGM - Disperta - PATPI - BI DIY, Yogyakarta

Wahono, S. K., Maryana, R., \& Kismurtono, M. (2009) Biogas Purification Process to Increase Generator Efficiency, American Institute of Physics Conference Proceedings, International Workshop on Advanced Material for New and Renewable Energy, June, $9^{\text {th }}-11^{\text {th }} 2009$, ISBN : 978-0-7354-0706-0, ISSN : 0094-243X, Jakarta

Wahono, S. K., Maryana, R., Kismurtono, M., Nisa, K., \& Poeloengasih, C. D. (2010) Local Zeolite - Gunungkidul Modification for Performance Improvement of Biogas as Electricity Resource, Proceeding on Seminar Nasional Rekayasa Kimia dan Proses, ISSN : 1411 - 4216, Chemical Engineering Department, Diponegoro University, Semarang

Weitkamp, J. \& Puppe, L. (1999) Catalysis and Zeolite Fundamentals and Applications, Springer-Verlag Berlin Heidelberg, Germany

Widayat, Mustafa, Roesyadi, A. \& Rachimoellah, M. (2008) Effect of $\mathrm{HCl}$ Concentration and Reactant Type in The Zeolite Catalysts Production for Dehydration Process of Natural Zeolite, Proceeding on Seminar Nasional Rekayasa Kimia dan Proses, ISSN : 1411 4216, Chemical Engineering Department, Diponegoro University, Semarang

Windarti, T. (2002) Effectiveness Profile of Acidic Zeolite Catalyst in Polyethylene Pyrolysis of Plastics Waste into Olefins Due to Temperature Changes, Routine DIK Research Report, Diponegoro University, Semarang

Tahir, R. \& Mustafa (2007) The Vegetable Waste was Converted into Biogas as Renewable Alternative Energy, Proceeding on Seminar Nasional Fundamental dan Aplikasi Teknik Kimia, ISSN : 14105667, Chemical Engineering Department, Institute Technology of Sepuluh November, Surabaya. 